\title{
ANALYSIS OF STABILITY OF STEEL MEMBERS WITH ACCOUNT OF THE FIXING CONDITIONS AND SUPPORTS STIFFNESS
}

\author{
V. Kondel, PhD., Assoc. Prof., D. Loboda, Student, \\ Poltava V.G. Korolenko National Pedagogical University
}

Abstract. The authors have studied the stability of compressed steel structures and parts of machines with account of support conditions. The analysis of experimental and theoretical data of the behaviour of compressed structures and their members is provided. The new approaches to the critical-load design with account of supports stiffness are described.

Key words: compressed steel members, buckling analysis, fixing conditions, supports stiffness.

\section{АНАЛІЗ СТІЙКОСТІ СТАЛЕВИХ ЕЛЕМЕНТІВ З УРАХУВАННЯМ УМОВ ЇХ КРІПЛЕННЯ ТА ЖОРСТКОСТІ ОПОР}

\author{
В.М. Кондель, доц., к.т.н., Д.О. Лобода, студ., \\ Полтавський національний педагогічний університет імені В.Г. Короленка
}

\begin{abstract}
Анотація. Робота присвячена дослідженню стійкості сталевих стиснутих елементів конструкиій та деталей машин з урахуванням умов їх кріплення. Запропоновано нові прості формули для розрахунків стиснутих елементів за критичними навантаженнями з урахуванням жорсткості опор.
\end{abstract}

Ключові слова: стиснуті сталеві елементи, розрахунки на стійкість, умови кріплення, жорсткість опор.

\section{АНАЛИЗ УСТОЙЧИВОСТИ СТАЛЬНЫХ ЭЛЕМЕНТОВ С УЧЕТОМ УСЛОВИЙ ИХ КРЕПЛЕНИЯ И ЖЕСТКОСТИ ОПОР}

\author{
В.Н. Кондель, доц., к.т.н., Д.А. Лобода, студ., \\ Полтавский национальный педагогический университет имени В.Г. Короленко
}

\begin{abstract}
Аннотация. Работа посвящена исследованию устойчивости стальных сжатых элементов конструкиий и деталей машин с учетом условий их крепления. Предложены новые простые формулы для расчетов сжатых элементов по критическим нагрузкам с учетом жесткости onop.
\end{abstract}

Ключевые слова: сжатые стальные элементы, расчеты на устойчивость, условия крепления, жесткость опор.

\section{Introduction}

Throughout the service life of the components, the members of the structures and parts of machines undergo various damage, the nature of which depends on their stress-strain state and working conditions (tension or compression, bending, torsion, torsional bending, variable load, etc.). To ensure the strength, reliability and durability of these members, numerous investi- gations are conducted on the processes of accumulation of damage, in particular, the origin and development of cracks in materials from which the structures and parts of machines are made. The main directions of preventing these negative phenomena or reducing their impact on the work of structures and parts of machines in general is to conduct timely and qualitative diagnostics, that is, to determine the technical condition of the object, research and design of rational cross- 
sectional forms, analysis of the fixing conditions and supports stiffness.

Among all the members of structures and parts of machines, significant parts are those that work on compression: columns, racks, upper belt trusses, screws in screw-nut transfers, screw springs, and others. They are designated not only for strength, but also for stability, because buckling is a very dangerous phenomenon, resulting in uncontrolled growth of deformation, and the compressed rod is destroyed almost instantly, which excludes any possibility of taking effective measures to prevent accidents and disasters. That is why, for a long time the stability of compressed members has been studied to develop measures to prevent such emergencies in the future. Since the main tasks of technical diagnostics are to control and predict the technical condition of the object, as well as to identify the causes of the violation of the normal operation of the structures compressed members and machines parts, additional studies should be carried out on the effect of the conditions of fastening the ends of the members and the supports stiffness on the values of critical or dangerous loading.

\section{Analysis of Publications}

Prominent scientists L. Euler, F. Engesser, F. Yasinsky, L. Tetmayer, T. Karman, F. Shenli and others $[1,2]$ contributed greatly to solving the problem of the stability of compressed members. They proposed formulas for determining the buckling load and stress that are unsafe for a compressed rod, depending on its flexibility, material, ways of fixing the ends and type of load.

Experiments have shown that taking into account the possible danger of instantaneous destruction of compressed members of structures and parts of machines due to uncontrolled growth of deformations at the marginal loading, these members should be calculated not only on the strength of the condition

$$
\sigma=\frac{F}{A} \leq[\sigma],
$$

but also for stability

$$
F \leq \frac{F_{c r}}{n_{s t}},
$$

where the coefficient of stock $n_{s t}$ is taken depending on the material, the shape of the section, the responsibility of the structure and the member (for steel from 1.8 to 3.5 , for iron from 5.0 to 6.0 , for wood from 2.8 to 3.2 ) $[1,2]$.

When calculating the allowable load on condition (2) it is necessary to find a buckling load $F_{c r}$, that is, the least axial force that can withstand a barely curved compressed rod in equilibrium.

For the first time, this problem was solved by L. Euler [1, 2], who proposed a formula for determining the buckling load for a rod with a hinged fix at both ends (Fig. 1)

$$
F_{c r}=\frac{\pi^{2} E I_{\min }}{l^{2}}
$$

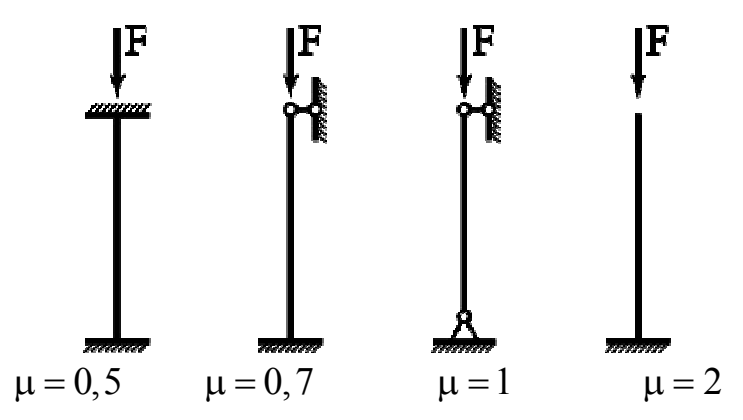

Fig. 1. Dependence of coefficients $\mu$ from the method of fixing the ends of the rod

Further studies have shown that the value of buckling load $F_{c r}$ for rods significantly depends on the ways of fixing their ends, so F. Yasinsky proposed the notion of a buckling length $\mu l[1,2]$, therefore formula (3) has the form

$$
F_{c r}=\frac{\pi^{2} E I_{\min }}{(\mu l)^{2}}
$$

Coefficient of buckling length of the rod $\mu$ ranges from 0.5 to 2 (Fig. 1), which means that, by equation (4), the rod, pinched from both ends $(\mu=0,5)$, can withstand 16 times the load than the same rod, pinched from one end and free from the other $(\mu=2)$.

It should be noted that the above cases of attachment of the ends of the rod (Fig. 1) in 
practice, are rarely found in their pure form. The most widespread cases are the fixation, when one end of the rod is stiffly fixed, and the other is elastically stuck $(\mu=0,7)$ or when both ends are elastically secured $(\mu=1)[1,2]$.

In order to carry out qualitative technical diagnostics of compressed members of structures and parts of machines, one should consider the impact of the stiffness supports on the value of the coefficient of buckling length $\mu$ and the magnitude of the buckling load $F_{c r}$.

\section{Purpose and Tasks}

The purpose of this article is to study the stability of compressed steel members of structures and parts of machines taking into account the conditions for fixing their ends and supports stiffness.

\section{Investigation of Stability of Compressed Steel Members with Account of Fixing Conditions and Supports Stiffness}

Let us consider the case where one end of the rod is rigidly fixed, and the other one is elastically obturated (Fig. 2). After the buckling, the elastically obturated end of the rack moves vertically to a magnitude $f_{b}$, with the result of an elastic reaction of the support $R_{b}$, which, in turn, is proportional to the deviation $f_{b}$

$$
R_{b}=c f_{b},
$$

where $c$ is coefficient of the stiffness of the support B.

We form the differential equation of the elastic line of the compressed rod after the buckling

$$
E I_{\min } \frac{d^{2} y}{d x^{2}}=F_{c r}\left(f_{b}-y\right)-c f_{b}(l-x) \text {. }
$$

Let us denote

$$
k^{2}=\frac{F_{c r}}{E I_{\min }} .
$$

Then equation (5) will look

or

$$
\frac{d^{2} y}{d x^{2}}=k^{2}\left(f_{b}-y\right)-\frac{c f_{b}}{E I_{\min }}(l-x)
$$

$$
\frac{d^{2} y}{d x^{2}}+k^{2} y=k^{2} f_{b}\left(1-\frac{c l}{F_{c r}}\right)-k^{2} \frac{c f_{b}}{F_{c r}} x
$$

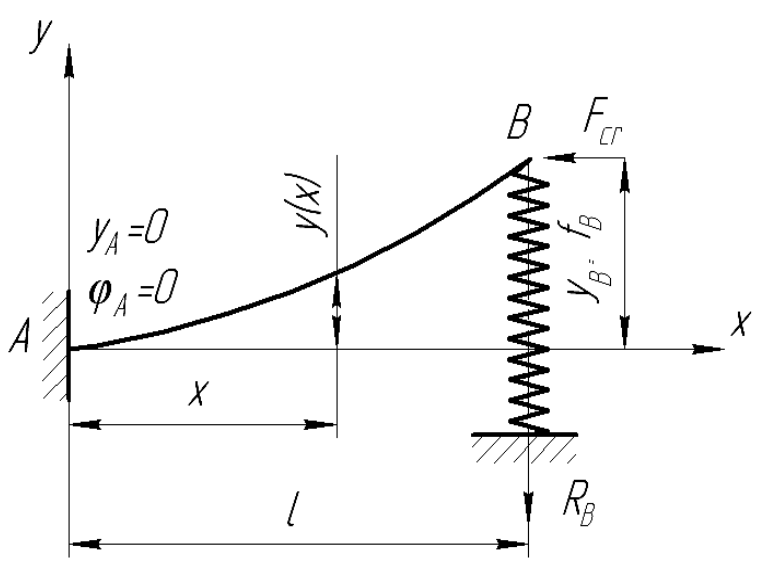

Fig. 2. Compressed rod, pinched from one end and elastically stuck on the other

The solution of this differential equation is dependence

$$
y=C \sin k x+D \cos k x+f_{b}\left(1-\frac{c l}{F_{c r}}\right)+\frac{c f_{b}}{F_{c r}} x .
$$

The constants integration $C$ and $D$ and the buckling load $F_{c r}$ will be determined from the following three boundary conditions:

when $x=0$ displacement and the angle of rotation of the section are zero:

$$
\begin{gathered}
y(0)=y_{A}=0 ; \\
\frac{d y}{d x}=\phi(0)=\phi_{A}=0 ;
\end{gathered}
$$

when $x=l$ displacement is equal to deviation $f_{b}$ (Fig. 2)

$$
y(l)=y_{b}=f_{b} .
$$

By the condition (9) we find from equation (8)

$$
D=-f_{b}\left(1-\frac{c}{F_{c r}} l\right) .
$$

To use the boundary condition (10) we define the derivative of the displacement $y$

$$
\frac{d y}{d x}=k C \cos k x-k D \sin k x+\frac{c}{F_{c r}} f_{b},
$$

where when $x=0$ 


$$
k C+\frac{c}{F_{c r}} f_{b}=0 \text { or } C=-\frac{c}{k F_{c r}} f_{b} .
$$

We substitute the expressions for constants integration $C$ and $D$ in the formula (8) and obtain the final equation of the curved axis of the compressed rod

$$
\begin{aligned}
y(x)=-\frac{c f_{b}}{k F_{c r}} \sin k x & +f_{b}\left(1-\frac{c l}{F_{c r}}\right) \cos k x+ \\
& +f_{b}\left(1-\frac{c l}{F_{c r}}\right)+\frac{c f_{b}}{F_{c r}} x .
\end{aligned}
$$

To determine the buckling load $F_{c r}$, we use the boundary condition (11). Thus, for $x=l$ with equation (12) we have

$$
\begin{aligned}
y(l)= & -\frac{c f_{b}}{k F_{c r}} \sin k l+f_{b}\left(1-\frac{c l}{F_{c r}}\right) \cos k l+ \\
& +f_{b}\left(1-\frac{c l}{F_{c r}}\right)+\frac{c f_{b}}{F_{c r}} l=f_{b},
\end{aligned}
$$

or

$$
-\frac{c}{k F_{c r}} \sin k l-\left(1-\frac{c l}{F_{c r}}\right) \cos k l=0 .
$$

After simple mathematical transformations, we obtain the equation

$$
\operatorname{tg} k l=k l\left(1-\frac{F_{c r}}{c l}\right)
$$

solving which, that is, determining the least root $k$, we can find the buckling load, since

$$
F_{c r}=k^{2} E I_{\min } \text {. }
$$

Let us consider two limiting cases. When $c=0$, we get $\operatorname{tg} k l=\infty$ or $k l=\pi / 2$, we have a case where the left end of the rod is stiffly fixed, and the right one is free, then $\mu=2$ (Fig. 1) and the buckling load

$$
F_{c r}=\frac{\pi^{2} E I_{\min }}{(2 l)^{2}}
$$

If $c=\infty$ (very stiff support), we get $\operatorname{tg} k l=k l$. Having solved this equation, we have $k l=\pi / a$, where $a=0.699155659643 \ldots \approx 0.7$, which gives the formula for the rod, one end of which is pinched, and the other is hinged (Fig. 1), then $\mu=0,7$ and the buckling load

$$
F_{c r}=\frac{\pi^{2} E I_{\min }}{(0,7 l)^{2}}
$$

Thus, if the coefficient of stiffness of the support $c$ varies from zero to infinity, then this can be taken into account by the coefficient of buckling length $\mu$, which, accordingly, varies from 2 to 0.7. This means that as the stiffness of the support increases, the coefficient $\mu$ decreases together with the stability of the compressed rod increases and the buckling strength value it can withstand [1-5]. We deduce the dependence of the coefficient of buckling length $\mu$ on the stiffness of the support $c$.

To study, we choose a steel compressed rack with a square cross-section of $5 \times 5 \mathrm{~cm}$. Let us define its length, taking into account that the Euler's formula (4) is applied only to flexible rods in which flexibility $\lambda \geq 100[1,2]$. Since

$$
\lambda=\frac{\mu l}{i_{\min }}
$$

where $i_{\min }$ is the minimum radius of inertia of the square cross-section of the rod

$$
i_{\min }=\sqrt{\frac{I_{\min }}{A}}=\sqrt{\frac{a^{4}}{12 a^{2}}}=\frac{a}{2 \sqrt{3}},
$$

then the length of the rack $l=\frac{\lambda i_{\min }}{\mu}=\frac{\lambda a}{2 \sqrt{3} \mu}$;

$l=\frac{100 \cdot 5}{2 \sqrt{3} \cdot 0.7}=206,2 \mathrm{~cm}$.

For calculations we accept a stable length $l=2,1 \mathrm{~m}$. Then the smallest and most flexible rod respectively makes up

$$
\begin{array}{r}
\lambda_{\text {min }}=\frac{0,699 \cdot 210 \cdot 2 \sqrt{3}}{5}=101,7 \text { and } \\
\lambda_{\max }=\frac{2 \cdot 210 \cdot 2 \sqrt{3}}{5}=291,0 .
\end{array}
$$

Stiffness of the rod with buckling

$$
E I_{\min }=2 \cdot 10^{5} \cdot \frac{0,05^{4}}{12}=0,10417 \mathrm{MH} \cdot \mathrm{m}^{2} \text {, }
$$

and buckling load, which will withstand the stability with minimal stiffness, that is, at $\lambda_{\text {min }}=101,7$ a rate of 


$$
\begin{aligned}
& F_{c r}=\frac{3,14159^{2} \cdot 0,10417}{(0,699 \cdot 2,1)^{2}}= \\
& =0,4771 \mathrm{MH}=477,1 \mathrm{\kappa H} .
\end{aligned}
$$

Parameter

$$
\begin{gathered}
k=\sqrt{\frac{F_{c r}}{E I_{\min }}}=\sqrt{\frac{\pi^{2} E I_{\text {min }}}{(\mu l)^{2} E I_{\text {min }}}}=\frac{\pi}{\mu l} ; \\
k=\frac{3,14159}{0,699 \cdot 2,1}=2,140 \mathrm{~m}^{-1},
\end{gathered}
$$

and the stiffness of the support $c$ can be determined from the equation (13)

$$
\begin{gathered}
c=\frac{k F_{c r}}{k l-\operatorname{tgkl}} ; \\
c=\frac{2,140 \cdot 477,1}{2,140 \cdot 2,1-\operatorname{tg}(2,140 \cdot 2,1)}= \\
=177497,3 \mathrm{KN} / \mathrm{m} .
\end{gathered}
$$

Similarly, we find the value of the buckling load $F_{c r}$, the parameter $k$ and the stiffness of the support $c$ at various values of the coefficient of buckling length from 0.7 to 2.0 at intervals of 0.1 . The results of calculations are presented in the Table, in which $\mu^{\exp }$ and $i \mu^{\text {th }}-$ the experimental and theoretical values of the coefficients of buckling length.

Table Results of calculations of the rod for stability

\begin{tabular}{|c|c|c|c|c|c|c|}
\hline$\mu^{\exp }$ & $\lambda$ & $\begin{array}{c}F_{c r}, \\
\mathrm{KN}\end{array}$ & $\begin{array}{c}k, \\
\mathrm{M}^{-1}\end{array}$ & $\begin{array}{c}c, \\
\mathrm{KN} / \mathrm{m}\end{array}$ & $\mu^{\text {th }}$ & $\begin{array}{c}|\delta|, \\
\%\end{array}$ \\
\hline 0,699 & 101,7 & 477,1 & 2,140 & 177497,3 & 0,699 & 0,00 \\
\hline 0,700 & 101,8 & 475,8 & 2,137 & 9528,8 & 0,704 & 0,57 \\
\hline 0,800 & 116,4 & 364,3 & 1,870 & 232,7 & 0,890 & 11,25 \\
\hline 0,900 & 130,9 & 287,8 & 1,662 & 153,0 & 0,969 & 7,67 \\
\hline 1,000 & 145,5 & 233,1 & 1,496 & 111,0 & 1,044 & 4,40 \\
\hline 1,100 & 160,0 & 192,7 & 1,360 & 83,2 & 1,121 & 1,91 \\
\hline 1,200 & 174,6 & 161,9 & 1,247 & 63,2 & 1,203 & 0,25 \\
\hline 1,300 & 189,1 & 137,9 & 1,151 & 48,1 & 1,290 & 0,77 \\
\hline 1,400 & 203,7 & 118,9 & 1,069 & 36,3 & 1,381 & 1,36 \\
\hline 1,500 & 218,2 & 103,6 & 0,997 & 27,0 & 1,476 & 1,60 \\
\hline 1,600 & 232,8 & 91,1 & 0,935 & 19,4 & 1,575 & 1,56 \\
\hline 1,700 & 247,3 & 80,7 & 0,880 & 13,2 & 1,677 & 1,35 \\
\hline 1,800 & 261,9 & 72,0 & 0,831 & 8,06 & 1,782 & 1,00 \\
\hline 1,900 & 276,4 & 64,6 & 0,787 & 3,71 & 1,890 & 0,53 \\
\hline 2,000 & 291,0 & 58,3 & 0,748 & 0,000161 & 2,000 & 0,00 \\
\hline
\end{tabular}

According to the table data, we construct a plot of the dependence of the stiffness support $c$ on the coefficient $\mu$ (Fig. 3), which confirms that to increase the stability of the compressed mem- ber (reducing the coefficient of buckling length $\mu$ ), it is necessary to increase the stiffness of the support $c$.

c, $\mathrm{KN} / \mathrm{m}$

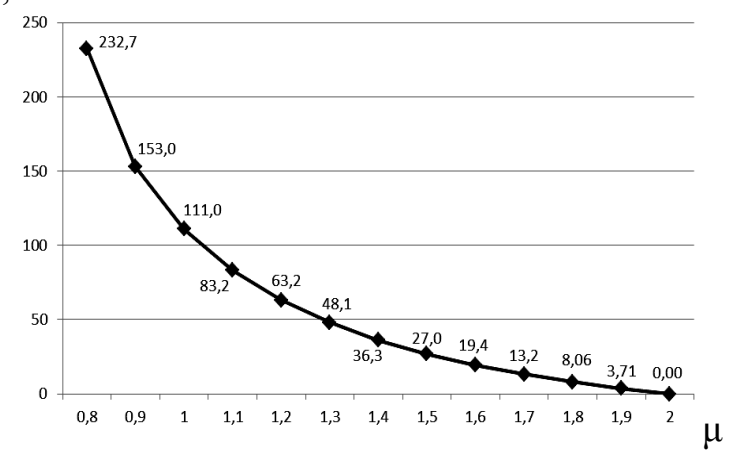

Fig. 3. Dependence of the stiffness of the support $c$ from the coefficient of buckling length $\mu$

This graph has the form of hyperbola, therefore, taking into account the condition that, when $c=0 \quad \mu=2$ and as well $c=\infty \quad \mu=0,699$, as the tabular data of the studies of the stability of the compressed members, a function $\mu=f(c)$ with sufficient for practical calculations can be accurately presented in the form

$$
\mu=0,699+\frac{1,301}{0,025 c+1},
$$

where $c$ is the stiffness of the support, which is measured in $\mathrm{kN} / \mathrm{m}$.

Using equation (16), we construct a graph of the dependence of the coefficient of buckling length of the rod $\mu$ from the stiffness of the support (Fig. 4).

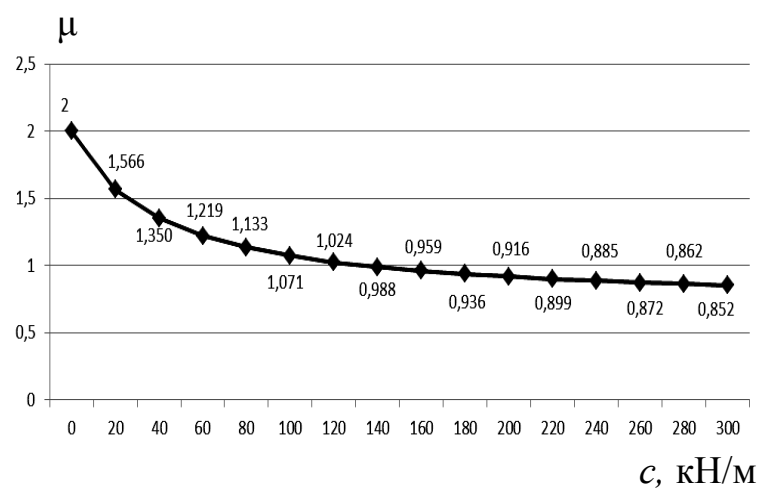

Fig. 4. Dependence the coefficient of buckling length $\mu$ from the stiffness of the support $c$ 
The curve $\mu=f(c)$, which as a function $c=f(\mu)$, takes a form of hyperbola, as evidence of a reduction coefficient $\mu$ (increased stability of the compressed rod) with increasing stiffness of the support. The value of theoretical coefficients of buckling length $\mu^{\text {th }}$, obtained by the formula (16), is not much different from experimental factors $\mu^{\text {exp }}$ in Table (average arithmetic deviation $\delta_{m}=2,28 \%$, average square deviation $-\sigma_{m}=3,82 \%$ ), and if you do not consider the data in the range $\mu=0,8 \ldots 1,0$, these deviations generally are within one percent $\left(\delta_{m}=0,91 \%\right.$ and $\left.\sigma_{m}=1,10 \%\right)$. This means that calculating buckling load from the known formula (4), the coefficient of buckling length of the rod $\mu$ can be determined by equation (16), taking into account the stiffness of the support $c$. It is also important to note that the coefficient $\mu$ significantly influences the values of buckling load, since in the Euler formula (4) it is in the square. This means that in the case when $c=\infty \quad(\mu=0,7)$, the stable will withstand load $2^{2} / 0,7^{2}=8,2$ times more than with $c=0$ $(\mu=2)$. The graph $\mu=f(c)$ shows that the increase in the stiffness of the support $c$ from zero to $100 \mathrm{kN} / \mathrm{m}$ (Fig. 4) affects more significantly the value of the coefficient $\mu$ increases the buckling load $\left(2^{2} / 1,071^{2}=3,5\right.$ times $)$, than 100 to $300 \mathrm{kN} / \mathrm{m}\left(1,071^{2} / 0,852^{2}=1,6\right.$ times $)$, which should be taken into account when conducting technical diagnostics of compressed rods.

The graph shows that the increase in the stiffness of the support from zero to $100 \mathrm{kN} / \mathrm{m}$ (Fig. 4) affects more significantly the value of the coefficient and increase of the buckling load (times), than the increase from 100 to $300 \mathrm{kN} / \mathrm{m}$ (times), which should be taken into account when conducting technical diagnostics of compressed rods.

\section{Conclusion}

When investigating the compressed members of structures and parts of machines, one should pay attention not only to the conditions of fastening the ends of the rods (Fig. 1), but also the stiffness of the support, which can be in the range from zero to infinity, which is taken into account by the coefficient of buckling length $\mu$ (from 2 to 0.7 ).
Calculating the buckling load by formula (4), as well as the flexibility of the rod $\lambda$ according to formula (15), the coefficient of buckling length of the rod $\mu$, sufficient for practical calculations can be determined by equation (16), taking into account the stiffness of the support.

To increase the stability of the compressed member, it is necessary to increase the stiffness of the support, taking into account the features of the graph $\mu=f(c)$ for reducing the impact on the coefficient $\mu$ of significant values of stiffness (Fig. 4).

Data on the conditions for fixing the ends of the rod and stiffness of the supports can be used in further studies of the stability of the members, in particular, in determining the stress reduction factor [6-10], designing compressed members of constant and variable cross-sections [4], rational forms of solid and composite cross-sections for compressed structures and their members [5], etc. These scientific developments will improve the reliability and durability of structural members and parts of machines and will avoid many accidents and disasters in the future.

\section{References}

1. Писаренко Г.С. Опір матеріалів / Г.С. Писаренко, О.Л. Квітка, Е.С. Уманський; за ред. Г.С. Писаренка. - К.: Вища школа, 1993. $-655 \mathrm{c}$.

2. Писаренко Г.С. Справочник по сопротивлению материалов / Г.С. Писаренко, А.П. Яковлев, В.В. Матвеев; отв. ред. Г.С. Писаренко. - К.: Наукова думка, 1988. $-736 \mathrm{c}$.

3. Кондель В. Дослідження стійкості стальних стиснених елементів конструкцій 3 урахуванням умов їх закріплення та жорсткості опор / В. Кондель, А. Павліченко // Вісник Тернопільського національного технічного університету імені Івана Пулюя. - 2011. - Т. 16, № 4. - С. 18-27.

4. Кондель В.М. Дослідження стійкості стальних стиснутих елементів сталого та змінного поперечних перерізів / B.М. Кондель, А.І. Павліченко // Фізикоматематичні науки: Вісник Київського національного університету імені Тараса Шевченка. - 2011. - № 4. - С.76-79.

5. Кондель В.М. Дослідження стійкості елементів конструкцій та деталей машин 
раціональних складених перерізів / В.М. Кондель, Р.Т. Холодков, М.М. Шевчук // Весник ХНАДУ: сб. науч. тр. 2015. - Вып. 68. - С. 50-56.

6. Кондель В. М. Аналіз коефіцієнтів поздовжнього згину 3 урахуванням міцності сталі / В.М. Кондель, Ю.О. Шевченко, Д.О. Лобода // Весник ХНАДУ: сб. науч. тр. - 2016. - Вып. 72. - С. 118-123.

7. Кондель В.М. Дослідження коефіцієнтів поздовжнього згинання 3 урахуванням міцності сталі для запобігання надзвичайним ситуаціям / В.М. Кондель, Ю.О. Шевченко, Д.О. Лобода // Вісник Львівського державного університету безпеки життєдіяльності: збірник наукових праць. - 2016. - № 13. - С. 79-86.

8. Васильченко В.Т. Справочник конструктоpa металлических конструкций / В.Т. Васильченко, А.Н. Рутман, Е.П. Лукьяненко. - 2-е изд., перераб. и доп. - К.: Будівельник, 1990. - 312 с.

9. Лихтарников Я.М. Расчет стальных конструкций: справочное пособие / Я.М. Лихтарников, Д.В. Ладыженский, В.М. Клыков. - 2-е изд., перераб. и доп. - К.: Будівельник, 1984. - 368 с.

10. Николаев Г.А. Сварные конструкции. Расчет и проектирование: учеб. для студ. вузов / Г.А. Николаев, В.А. Винокуров; под ред. Г. А. Николаева. - М.: Высшая школа, 1990. -446 c.

\section{References}

1. Pysarenko H. S., Kvitka O. L., Umans'kyy E. S. Opir materialiv [Strength of materials], Kyiv, Vyshcha shkola Publ., 1993, $655 \mathrm{p}$.

2. Pisarenko G. S., Jakovlev A. P., Matveev V. V. Spravochnik po soprotivleniju materialov [Handbook on strength of materials], Kyiv, Naukova dumka Publ., 1988, $736 \mathrm{p}$.

3. Kondel' V., Pavlichenko A. Doslidzhennya stiykosti stal'nykh stysnenykh elementiv konstruktsiy $z$ urakhuvannyam umov yikh zakriplennya ta zhorstkosti opor [The investigation of stability of compressed steel members with accountance of fixing conditions and stiffness supports]. Visnyk Ternopil's'koho natsional'noho tekhnichnoho universytetu imeni Ivana Pulyuya, 2011, vol. 16, pp. 18-27.

4. Kondel' V. M., Pavlichenko A. I. Doslidzhennya stiykosti stal'nykh stysnutykh elementiv staloho ta zminnoho poperechnykh pereriziv [The stability investigation of compressed steel members of constant and variable cross sections]. Fizyko-matematychni nauky: Visnyk Kyyivs'koho natsional'noho universytetu imeni Tarasa Shevchenka, 2011, vol. 4, pp. 76-79.

5. Kondel' V. M., Kholodkov R. T., Shevchuk M. M. Doslidzhennya stiykosti elementiv konstruktsiy ta detaley mashyn ratsional'nykh skladenykh pereriziv [Investigation of stability of structures and parts of machines of rational composite sections]. Vestnik Khar'kovskogo natsional'nogo avtomobil'no-dorozhnogo universiteta: sbornik nauchnyh trudov, 2015, vol. 68, pp. 50-56.

6. Kondel' V. M., Shevchenko Yu. O., Loboda D. O. Analiz koefitsiyentiv pozdovzhn'oho zhynu z urakhuvannyam mitsnosti stali [Analysis of stress reduction factors taking into account the steel strength]. Vestnik Khar'kovskogo natsional'nogo avtomobil'no-dorozhnogo universiteta : sbornik nauchnyh trudov, 2016, vol. 72, pp. 118-123.

7. Kondel' V. M., Shevchenko Yu. O., Loboda D. O. Doslidzhennya koefitsiyentiv pozdovzhn'oho zhynannya z urakhuvannyam mitsnosti stali dlya zapobihannya nadzvychaynym sytuatsiyam [The investigation of stress reduction factors with accountance of steel strength for prevention of emergency situations]. Visnyk L'vivs'koho derzhavnoho universytetu bezpeky zhyttyediyal'nosti: zbirnyk naukovykh prats', 2016, vol. 13, pp. 79-86.

8. Vasil'chenko V. T, Rutman A. N., Luk'janenko E. P. Spravochnik konstruktora metallicheskih konstrukcij [Reference designer of metal structures], Kyiv, Budivel'nyk Publ., 1990, $312 \mathrm{p}$.

9. Lihtarnikov Ja. M., Ladyzhenskij D. V., Klykov V. M. Raschet stal'nyh konstrukcij : spravochnoe posobie [Calculation of steel structures : a handbook], Kyiv, Budivel'nyk Publ., 1984, 368 p.

10. Nikolaev G. A., Vinokurov V. A. Svarnye konstrukcii. Raschet $i$ proektirovanie [Welded construction. Calculation and design], Moscow, Vysshaja shkola Publ., 1990, $446 \mathrm{p}$.

Рецензент: В.П. Кожушко, профессор, д.т.н., ХНАДУ. 